\title{
Job stress and its relation to the quality of work life at a sample of social workers in special intellectual education schools
}

\section{Suzan Adel Mohammed Ahmed Rashed (PhD)}

Assistant Professor at Social Casework department Higher Institute of Social work at Banha

\section{Yaser Snoubar (PhD)}

Assistant Professor, Social Sciences Department (Social Work Program)

College of Arts and Sciences Qatar University, Doha, Qatar 
Job stress and its relation to the quality of work life at a sample of social workers in special intellectual education schools

\section{Yaser Snoubar (PhD)}

Assistant Professor, Social Sciences Department (Social Work

Program)

College of Arts and Sciences Qatar University, Doha, Qatar

\section{Suzan Adel Mohammed Ahmed Rashed (PhD)}

Assistant Professor at Social Casework department

Higher Institute of Social work at Banha

\section{Abstract:}

The study aimed to determine the level of job stress among social workers and its relation to the quality of work life. In light of this, the job stress scale and the quality of work life scale were applied to the study sample 180 social workers working in special intellectual education schools in Cairo Governorate. The results of the study indicate that the level of job stress of social workers in special intellectual education schools is high with the arithmetic mean of 4.35. As for the quality of work life of the social workers (sample study), it is low; the arithmetic mean is equal to (1.59). This means, whenever the job stress in a sample of study from social workers increases, the quality of work life decreases. Conversely, whenever the job stress decreases, their quality of work life increases. These results were consistent with research hypotheses. The study found out that, quality of work life has a role in reducing the phenomenon of job stress among social workers in special intellectual education schools. This study is one of the rare studies, which link the variable dimensions of the quality of work life and job stress to social workers.

Key words: quality of work life, Job stress, social workers, special intellectual education schools

\section{Introduction:}

Attention to quality of work life is the main support for creating a safe, healthy, and appropriate working environment in which there are forms of participation of workers in management processes, decision-making on one hand, and attention to family and family life on the other hand (Ibrahim Al-Mahasna, 2014:87). The quality of work life prevailing in organizations is one of the sources of satisfaction of working individuals and an indicator of the special climate that separate the organization from other organizations. (Iyad Al-Dajani, 2010: 32). Therefore, focusing and attending to the quality of work life leads to ways that will lead to fundamental 
transformations in the organization in order to achieve results and increase work satisfaction in workers and thus increase productivity. (Mahdy Zuwilif, 2003: 54).

The workers in the field of intellectual education, especially social workers, are more vulnerable to job stress than others, especially where they choose their profession and they have a strong desire to help others, and spend a lot of time. However, they were confronted with challenges and different degree of problems. So they work with full effort but the problems continue, and this caused exhaustion and tiredness as a result of feeling that they are useless (Juma Syed Yusuf, 2006: 212). This is illustrated by some studies, including the Mangle Michael study (2014), which indicated that the intervention was very effective in enhancing the working relationships and to emphasize the positiveness in the psychologically difficult work, in addition tolearn how to avoid or reduce job stress. Adams, Richard, et al. (2008) conducted a study to assess the differences between PTSD and job stress and PTSD feasibility in predicting psychological suffering. The results revealed that both PTSD and job stress were associated with psychological stress after controlling the risk factors.

Job stress levels vary depending on the type of work stress and its nature. Thus, the most stressful fields of work are those fields that have direct interaction with people, in which individuals devote themselves to serving others (Anas Abbas, 2011, 214). Which means that there is pressure on social workers leading to a state of job stress they experience, and this has been confirmed by the results of previous studies. For example, the study conducted by Ahmed Mohammed Al-Rantissi (2015): aimed st determining the level of stress exerted on social workers in the directorates of social affairs in the Gaza Strip. The results of the study revealed that the most pressure on social workers, leading to the state of job stress are; the stress due to motivational factors and this is about $70 \%$, stress as a result of organizational and administrative factors is $68 \%$, the stress from the institution where the social worker works is $66 \%$, the stress resulting from quality and nature of clients is $59 \%$, the stress related to the status of the social work profession within the community is $54 \%$, and this is followed by the stress related to the personality of the social worker himself by $53 \%$. On the other hand, this study was in response to many of the recommendations recommended by researchers to study the phenomenon of job stress for social workers.As well as the 
study conducted by Abdel-Jaber Al-Ahmad (2014) concluded that there is a statistically significant relationship is inversely proportional to social stress and the quality of work performance. A study conducted by Rana Refaat Shawkat (2013) indicates that there is a relationship between the psychological stresses that cause job stress and job satisfaction for social workers who are working in prisons.

The study of Abdel Halim El Sayed (2011), concluded that the main hypothesis of the effectiveness of the social work intervention program in alleviating the job stress of social workers in junior high schools are correct. Mark Brackett et al. (2010), conducted a study aimed to detect the effect of gender and emotional stress control on job stress in a sample of secondary school teachers in Britain, found that these factors are closely negative correlated with level of job stress among teachers, and positive correlation is associated with a sense of high level of personal achievement and The low level of feeling of fatigue and psychological stress.

The job stress of the social worker is due to several factors, the most important of which is his desire for high wages, his or her organization's recognition of the importance of his social status, and the society's view of him or her as evidence of successful and excellent (Yusuf Mustafa et al., 2014: 132). This is confirmed by some studies and applied research, including the study of Marwa Abdel Raouf Mahmoud (2012), which aimed to identify the effectiveness of a training program based on music therapy in reducing the stress of the work of a sample of special education teachers, and its impact on their job satisfaction and self esteem. The results of the study showed that there is a decline in the job stress, and increase the rate of job satisfaction and professional, and self-esteem, which confirms the impact of the guidance program even after the follow-up application. The study of Zaid Mishary Al-Khubari (2011) revealed that there is an inverse relationship between psychological stress and job satisfaction among teachers of intellectual education in the state Kuwait.

The Webb, Angela (2014) study, aimed to discover the extent of the stress exposed by workers at the Federal Union of Prisons Office and the extent of psychological stress they have and how satisfied they work under such stress, and all workers exposed to psychological stress are exposed to job stress, thus adversely affecting job satisfaction. As the study of Jason Teven (2007), showed that the attention of the school administration with teachers was negatively 
correlated with job stress and low self-motivation level. It also indicated that the stress of the job led to poor mood of teachers and a decline in the level of job satisfaction.

Through a review of previous studies regarding quality of work life, the researchers found that there is a fact that: Previous studies on quality of work life did not address linking the two variables together (job stress and quality of work life). Most of the previous studies were applied either to the quality of work life dimension only, or to the job stress variable only, or linking them to other variables such as: (performance, satisfaction, employment, organizational commitment). Therefore, the present study focused on that the quality of work life and its role in reducing the phenomenon of job stress among social workers in special intellectual education schools by examining the dimensions of quality of work life and its impact on job stress. Where this study is one of the few studies that link the variable dimensions of the quality of work life and job stress of social workers, where there are no national and international studies linked these two variables together in one study.

\section{Study Problem:}

In view of the nature of the profession of social work, social workers in many fields of practice work and are exposed to many cases and problems that have negative dimensions and directly effect on the effectiveness of their professional performance. Special intellectual education schools are one of the important areas in which a social worker works. Therefore, the problem of research is to identify the relationship of job stress and quality of work life of a sample of social workers in special intellectual education schools. In addition, focusing on the role of quality of work life in reducing the phenomenon of job stress among social workers in this field practice.

\section{Study Objectives:}

1. Identify the level of job stress among social workers (study sample) and its relation to the quality of work life.

2. Identify of differences in the degree of job stress among social workers according to gender, age, experience, academic qualification variable.

3. Provide proposals to reduce job stress among social workers (the study sample). 
Study Hypotheses: The current research attempts to test the following hypotheses:

First Hypothesis: The job stress of social workers in special education schools is high.

Second Hypothesis: The quality of work life of social workers in special intellectual education schools is low.

Third Hypothesis: There is a statistically significant relationship between job stress and quality of work life among social workers in special intellectual education schools.

Fourth Hypothesis: There is a statistically significant relationship between the demographic variables (gender, age, marital status, academic qualification, and years of experience) and the degree of job stress in the study sample.

Fifth Hypothesis: There is a statistically significant relationship between demographic variables (gender, age, marital status, academic qualification, and years of experience) and quality of work life in them sample study.

\section{Study Concepts:}

The concept of job stress: Job stress is defined as a type of response (physical or psychological) to an accident or external condition that places particular physical and psychological requirements on the individual and causes a shift from the exercise of his normal work (Ibrahim, 2012). It is also defined as the situation in which the interaction between the work conditions and the personality of the individual affects his or her psychological and physical state that may lead to a change in his or her normal behavior (Mustafa et al., 2014) It is defined by Abu Fara (2009) as an abnormal state of emergency affects the individual as a result of various internal and external quantitatively and qualitatively influences, and different in their effects and consequences on the performance of the individual depending on the individual differences between individuals and the disappearance of the effects of this situation on the individual vary from person to person. (Abu Fara et al., 2009: 212).

The researchers refer to job stress in the current study as: responding to certain pressures which constitute a psychological and social burden on the social worker and surpassing its capabilities in the face of these pressures, thus reducing the effectiveness of his professional performance. 
It is measured procedurally by a high degree on the dimensions of the Job Stress Scale tool for social workers who are subject of current study.

The concept of Quality of Work Life: The quality of work life is defined as a set of integrated, planned and ongoing processes that aim to improve the various aspects that affect the employees' work lives and them personal lives also, which in turn contributes to the achievement of the strategic objectives of the organization, its employees, and its clients (Sayed Jad Alrab, 2008, p. 99). It is also defined as the positive or non-positive attributes or aspects associated with the work environment as perceived by workers (Muayad Alsalem, 2008: 65). Some pointed out that the quality of work life is the way to motivate workers by meeting and satisfying their economic, social and psychological needs, which focus on the plans and designs of the work and its system, as well as the importance of human relations (Abbas Jawad, Najm Al-Azzawi, 2010: 123). The researchers refer to the quality of work life in the current study as "a work environment in which physical and moral factors are available in all various dimensions well, which is reflected positively on the social worker who is satisfied with the safety of the job and does his utmost to serve the institution."

It is measured procedurally by a high degree on the dimensions of the Quality of Work Life Scale tool for social workers who are subject of current study.

Special Intellectual Education Schools: Schools that offer a range of specialized educational programs offered to non-ordinary people, in order to help them develop their abilities to the fullest possible, in addition to helping them achieve themselves, and helping them to adapt (Al -Rousan, 2001:17).

Methodology: This study mainly adopted a descriptive comparative analytical methodology; the problem of study is predominantly determinative and it aims at estimating the current situation "Job stress and its relation to the quality of work life at a sample of social workers in special intellectual education schools". The researchers adopted the social survey method; the social survey method fits this study in terms of its subject matter, or the adequacy of the data, which can be collected to describe the relationship between job stress and the quality of work life in a sample of social workers in special intellectual education schools. 
Sample of the study: A sample of the social workers in special intellectual education schools in Cairo Governorate was selected. The sampling frame has been identified in the education sector for the special intellectual education schools of the Cairo Directorate with total size of (340) according to the Steven Thompson formula and application of sample conditions. The total number (180) were randomly assigned. Sample consisted of (80) males and (100) females according to the following conditions: (A) They should work in special intellectual education schools in the preparatory stage affiliated to Cairo Educational Administration. (B) These schools should be government. (C) Agree to cooperate with the researcher.

Tools of the study: The researchers relied on two measures to collect data, and study and analysis of the subject of the study:

A) Job Stress Scale among social workers (prepared by the researcher). (B) Quality of Work Life Standard (prepared by Dr. Mohamed Abdel Hakim Khalaf). The building of the tools that were used in the study are clarify as the following:

A- Job Stress Scale among social workers: In designing the scale, the researcher studied the previous studies and research and theoretical writings which dealt with job stress and its sources. The scale was designed in two parts, as follows:

Part 1: Includes personal data (gender, marital status, age, academic qualification, and years of experience).

Part 2: consists of (33) items to measure the job stress spread over four dimensions: (first dimension: emotional stress - the second dimension: personal stress - the third dimension: stress in the work environment - the fourth dimension: health and physical stress).

The researcher took into account in the design of the scale as follows: (A) Determine the type of data to be obtained. (B) Development of terms that are closely linked to the aim of the study. (C) Ease of terms and clarity of content and be sure that when testing the scale. (D) Using appropriate the language to the educational and cultural level of social workers. The researcher adopted the five-dimensional Likert scale to determine the degree of each term. Two formulas of answers were use in accordance with formula paragraphs of scale, as shown in the following table: 
Print ISSN: 2356-9204 Online ISSN: 2356-9212 Vol 8, Issue 1, June 2019

Table 1: Shows the weights of the paragraphs

\begin{tabular}{|c|c|c|c|c|c|}
\hline Response & $\begin{array}{c}\text { Strongly } \\
\text { Agree } \\
\end{array}$ & Agree & Neutral & Disagree & $\begin{array}{l}\text { Strongly } \\
\text { disagree } \\
\end{array}$ \\
\hline Weight & 5 & 4 & 3 & 2 & 1 \\
\hline
\end{tabular}

\section{Correction:}

As the total score increases, it serves as an indicator of job stress, and the maximum degree that can be obtained on the scale as a whole is (165), and the lowest score is (33).

\section{Honesty and consistency of the Job Stress scale:}

A - Honesty: The researcher relied on two types of honesty:

1. The validity of the arbitrators (the virtual): It includes the ratios of the agreement of the arbitrators on the paragraphs of the scale, Where the Job Stress Scale of social workers was presented to a number of professors of social work, psychology, and field practice to be judged in light of:

1. The extent to which the phrase is linked to each axis of the study.

2. In terms of phrase formulation.

3. In terms of content.

Accordingly, the general dimensions of the scale have been modified. Some phrases have been modified and the phrases with less than $85 \%$ of agreement have been deleted. The ratio of the agreement has been calculated according to the Geithman equation.

Internal consistency reliability (factor): The researcher calculated the internal consistency of the scale paragraphs on a sample size of (21) single:

Table 2: The internal consistency between the variables of the Job Stress Scale of social workers and the total degree

\begin{tabular}{||c||c||c||c||}
\hline M & \multicolumn{1}{|c||}{ Scale dimensions } & $\begin{array}{c}\text { Correlation coefficient } \\
\text { with total score }\end{array}$ & $\begin{array}{c}\text { Level of } \\
\text { significance }\end{array}$ \\
\hline \hline 1 & $\begin{array}{l}\text { The first dimension: } \\
\text { emotional stress }\end{array}$ & 0.687 & 0.000 \\
\hline \hline 2 & $\begin{array}{l}\text { Second dimension: } \\
\text { personal stress }\end{array}$ & 0.718 & 0.000 \\
\hline \hline 3 & $\begin{array}{l}\text { Third dimension: Stress } \\
\text { in the work } \\
\text { environment }\end{array}$ & 0.848 & 0.000 \\
\hline \hline 4 & $\begin{array}{l}\text { The fourth dimension: } \\
\text { health and physical } \\
\text { stress }\end{array}$ & 0.789 & 0.000 \\
\hline
\end{tabular}


Illustrated by the table above, the dimensions of job stress scale of social workers have a statistically significant at the level of (0.05), this gives an indication of the high coefficients of internal consistency, as well as its reference to the high sincerity and enough of indicators to be trusted in the application of the current study.

B- Reliability: The researcher used two methods to ensure the reliability of the scale:

1. Alpha Cronbach: The researcher applied the scale to a sample and determined the psychometric characteristics, and then re-applied on the same sample after a period of time (15) days, ie, two weeks between the first application and the second. The researcher then calculated the reliability of the job stress scale of the social workers, by using the reliability coefficient for alpha cronbach. The following table shows the reliability coefficient of the scale dimensions:

Table 3: Coefficient of reliability results by using (alphacronbach) for the job stress scale of social workers

\begin{tabular}{||l||l||c||}
\hline $\mathbf{M}$ & \multicolumn{1}{|c||}{ Dimension } & $\begin{array}{c}\text { Alpha Cronbach } \\
\text { Coefficient }\end{array}$ \\
\hline \hline 1 & $\begin{array}{l}\text { Reliability job stress scale of the social } \\
\text { workers as a whole }\end{array}$ & 0.931 \\
\hline
\end{tabular}

The previous table shows the job stress scale of the social workers. It has statistically high reliability; which enabling us to rely on the findings of the tool.

2. Split-half: The researcher used the Spearman-Brown Prophecy Formula for the semantic fraction where the phrases of each variable were divided into two halves. The first section includes the values obtained from responses to individual paragraphs, and the section includes the values expressed in the double paragraphs, and the results of the test are as follows:

Table 4: Coefficient of reliability results by using SpearmanBrown Formula for split-half for the job stress scale of social workers

\begin{tabular}{|c|c|c|}
\hline$M$ & Dimension & $\begin{array}{c}\text { Spearman- } \\
\text { Brown Formula }\end{array}$ \\
\hline 1 & $\begin{array}{c}\text { Reliability job stress scale of the social } \\
\text { workers as a whole }\end{array}$ & 0.911 \\
\hline
\end{tabular}


The above table shows that most of the reliability coefficients of variables have a high degree of reliability; thus their results can be relied upon and the tool were finalized.

B - Quality of Work Life Scale: (Prepared by: Mohamed Abdel Hakim Khalaf, 2018)

The scale consists of (30) items to measure the quality of work life divided into four dimensions: (participation in management, wages and financial rewards, social relations, security and job stability). The researcher adopted the five-dimensional Likert scale to determine the degree of each paragraph. Two formulas of answers were used to match the formula of the scale paragraphs as shown in the following table:

Table 5: Weights of the paragraphs

\begin{tabular}{||c||c||c||c||c||c||}
\hline Response & $\begin{array}{c}\text { Strongly } \\
\text { Agree }\end{array}$ & Agree & Neutral & Disagree & $\begin{array}{c}\text { Strongly } \\
\text { disagree }\end{array}$ \\
\hline \hline Weight & $\mathbf{5}$ & $\mathbf{4}$ & $\mathbf{3}$ & $\mathbf{2}$ & $\mathbf{1}$ \\
\hline
\end{tabular}

Correction:

As the total score increases, this was an indicator of quality of work life, and the maximum degree that can be obtained on the scale as a whole, is (150), and the lowest score is (30), as follows:

Table 6: The distribution of the grades of partial measures and the total degree of quality of the work life of social workers

\begin{tabular}{||l||c||c||c||}
\hline $\begin{array}{c}\text { Quality of work life } \\
\text { dimensions }\end{array}$ & $\begin{array}{c}\text { Low } \\
\text { grade }\end{array}$ & $\begin{array}{c}\text { Middle } \\
\text { grade }\end{array}$ & $\begin{array}{c}\text { High } \\
\text { grade }\end{array}$ \\
\hline \hline Participation in management & $\mathbf{1 0}$ & $\mathbf{3 0}$ & $\mathbf{5 0}$ \\
\hline \hline Wages and financial rewards & $\mathbf{9}$ & $\mathbf{2 7}$ & $\mathbf{4 5}$ \\
\hline \hline Social relations & $\mathbf{5}$ & $\mathbf{1 5}$ & $\mathbf{2 5}$ \\
\hline Safety and functional stability & $\mathbf{6}$ & $\mathbf{1 8}$ & $\mathbf{3 0}$ \\
\hline \hline Total Scale & $\mathbf{3 0}$ & $\mathbf{9 0}$ & $\mathbf{1 5 0}$ \\
\hline
\end{tabular}

Measuring the scale:

The researcher in the current study re-honesty and reliability as follows:

A - Honesty: The researcher relied on two types of honesty:

1. The validity of the arbitrators (the virtual): It includes the ratios of the agreement of the arbitrators on the paragraphs of the scale, where the Quality of Work Life Scale of social workers was presented to a number of professors of social work, psychology, and field practice to be judged in light of: 
1. The extent to which the phrase is linked to each axis of the study.

2. In terms of phrase formulation.

3. In terms of content.

Accordingly, the general dimensions of the scale have been modified. Some phrases have been modified and the phrases with less than $85 \%$ of agreement have been deleted. The ratio of the agreement has been calculated according to the Geithman equation.

2. Internal consistency reliability (factor): The researcher calculated the internal consistency of the scale paragraphs on a sample size of (21) single:

Table 7: The internal consistency between the variables of the Quality of Work Life Scale of social workers and the total degree

\begin{tabular}{||l||c||c|c||}
\hline \hline M & Scale dimensions & $\begin{array}{c}\text { Correlation } \\
\text { coefficient with } \\
\text { total score }\end{array}$ & $\begin{array}{c}\text { Level of } \\
\text { significance }\end{array}$ \\
\hline \hline 1 & Participation in management & $\mathbf{0 . 8 8 7}$ & $\mathbf{0 . 0 0 0}$ \\
\hline \hline 2 & Wages and financial rewards & $\mathbf{0 . 9 1 1}$ & $\mathbf{0 . 0 0 0}$ \\
\hline \hline 3 & Social relations & $\mathbf{0 . 8 9 1}$ & $\mathbf{0 . 0 0 0}$ \\
\hline \hline 4 & Safety and functional stability & $\mathbf{0 . 8 2 1}$ & $\mathbf{0 . 0 0 0}$ \\
\hline
\end{tabular}

Illustrated by the table above, the dimensions of quality of work life scale of social workers have a statistically significance, at a level of (0.05). This gives an indication of the high coefficients of internal consistency as well as referring to the high sincerity and enough of indicators to be trusted in the application of the current study.

B- Reliability: The researcher used two methods to ensure the reliability of the scale:

1. Alpha Cronbach: The researcher applied the scale to a sample and determined the psychometric characteristics, and then re-applied on the same sample after a period of time (15) days, i.e. two weeks between the first application and the second. The researcher then calculated the reliability of the quality of work life scale of the social workers, by using the reliability coefficient for alpha Cronbach. The following table shows the reliability coefficient of the scale dimensions: 
Table 8: Coefficient of reliability results by using (alphacronbach) for the quality of work life scale of social workers

\begin{tabular}{||c|c|c||}
\hline M & Dimension & $\begin{array}{c}\text { Alpha Cronbach } \\
\text { Coefficient }\end{array}$ \\
\hline \hline 1 & $\begin{array}{c}\text { Reliability quality of work life scale of } \\
\text { the social workers as a whole }\end{array}$ & $\mathbf{0 . 9 1 6}$ \\
\hline
\end{tabular}

The previous table shows the quality of work life scale of the social workers. It has statistically high reliability; which enables us to rely on the findings of the tool.

2. Split-half: The researcher used the Spearman-Brown Prophecy Formula for the semantic fraction where the phrases of each variable were divided into two halves. The first section includes the values obtained from responses to individual paragraphs. The second section includes the values expressed in the double paragraphs, and the results of the test are as follows:

Table 9: Coefficient of reliability results by using SpearmanBrown Formula for split-half for the quality of work life scale of social workers

\begin{tabular}{||c|c||c||}
\hline$M$ & Dimension & $\begin{array}{c}\text { Spearman-Brown } \\
\text { Formula }\end{array}$ \\
\hline \hline 1 & $\begin{array}{c}\text { Reliability of quality of work life scale of } \\
\text { the social workers as a whole }\end{array}$ & 0.911 \\
\hline
\end{tabular}

The above table shows that most of the reliability coefficients of variables have a high degree of reliability. Thus their results can be relied upon and the tool became finalized.

Statistical relationship: After the process of data collection and review, the researcher encodes data and discharged by using the Statistical Analysis Program (SPSS V 25.0) and applied the following few statistics:

1. Duplicates and percentages: to describe the characteristics of the study community. 2. Arithmetic level:

Table 10: Levels of arithmetic mean of the five-point scale

\begin{tabular}{l|c|}
\hline $\begin{array}{l}\text { If the average value of the phrase or dimension } \\
\text { ranged between } 1-2.33\end{array}$ & low level \\
\hline $\begin{array}{l}\text { If the average value of the phrase or dimension has } \\
\text { varied between more than } 2.34-3.66\end{array}$ & Middle \\
level
\end{tabular}


Egyptian Journal of Social Work (EJSW) http://ejsw.journals.ekb.eg

Print ISSN: 2356-9204 Online ISSN: 2356-9212 Vol 8, Issue 1, June 2019

3.Standard deviation 4. Cronbach's Alpha 5. Pearson Correlation Coefficient 6. Spearman Brown Coefficient 7. Chi-Square 8. Gamma

Results:

First: Statistical description of the sample of the study according to personal data:

Table 11: The characteristics of the study sample

\begin{tabular}{|c|c|c|c|}
\hline Sr. & Gender & $\overline{\mathrm{X}}$ & $\%$ \\
\hline 1 & Male & 80 & 444.4 \\
\hline 2 & Female & 100 & 55.6 \\
\hline Sr. & Social Status & $\overline{\bar{X}}$ & $\%$ \\
\hline 1 & Single & 16 & 8.9 \\
\hline 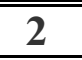 & Married & 144 & 80.0 \\
\hline ב3 & Detached & 14 & 7.8 \\
\hline 4 & Widowed & 6 & 3.3 \\
\hline Sr. & Age & $\bar{X}$ & $\%$ \\
\hline 1 & $20-29$ & 95 & 52.8 \\
\hline 2 & 30-39 & 38 & 21.1 \\
\hline$\overline{3}$ & $40-49$ & 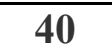 & 22.2 \\
\hline \multirow[t]{3}{*}{ 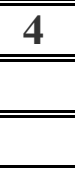 } & $50+$ & 7 & 3.9 \\
\hline & Mean & 32.30 & \\
\hline & SD & 7.870 & \\
\hline Sr. & Qualification & $\bar{X}$ & $\%$ \\
\hline 1 & $\begin{array}{l}\text { Average qualification in } \\
\text { social service }\end{array}$ & 30 & 16.7 \\
\hline 2 & Bachelor in social work & 121 & 67.2 \\
\hline 3 & Diploma (s) & 16 & 8.9 \\
\hline 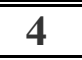 & Masters & 10 & $\overline{5.6}$ \\
\hline 5 & Ph.D & 3 & 1.7 \\
\hline Sr. & Years of experience & $\bar{X}$ & $\%$ \\
\hline 1 & $-\varepsilon$ & 32 & 17.8 \\
\hline 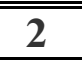 & $\begin{array}{c}4-7 \\
\end{array}$ & 102 & "56.7 \\
\hline 3 & 8-11 & 21 & 11.7 \\
\hline \multirow[t]{3}{*}{ 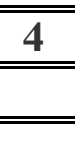 } & $12+$ & 25 & 13.9 \\
\hline & Mean & 6.58 & \\
\hline & SD & 4.114 & \\
\hline
\end{tabular}


The demographic data of the study sample of social workers showed that (ND 180), among them (55.6\%) females were compared to males $(44.4 \%)$. With regard to marital status of the study sample, the results indicated that the percentage of married persons reached $(80.0 \%)$. The average age of the sample as a whole was 32.50 years and the sample was concentrated in the age group between (SD 7.870; Range D 30-39).

The majority of the sample $(67.2 \%)$ of the study confirmed that they hold a bachelor's degree in social work. Their average work experience was 6.68 years and their proportion concentrated in (SD 4.114; Range D 4-7).

Testing the study hypotheses:

First Hypothesis: The job stress of social workers in special education schools is expected to be high.

Table 12: The level of job stress among social workers $(\mathrm{N}=180)$

\begin{tabular}{||l||c||c||c||c||}
\hline \multicolumn{1}{|c||}{ Dimensions } & Mean & $\begin{array}{c}\text { Standard } \\
\text { Deviation }\end{array}$ & $\begin{array}{c}\text { Ran } \\
\text { kin } \\
\text { g }\end{array}$ & Level \\
\hline Emotional stress & 4.39 & 0.415 & 3 & High \\
\hline \hline Personal stress & 4.41 & 0.470 & 2 & High \\
\hline $\begin{array}{l}\text { Stress in the work } \\
\text { environment }\end{array}$ & 4.46 & 0.419 & 1 & High \\
\hline $\begin{array}{l}\text { Health and physical } \\
\text { stress }\end{array}$ & 4.25 & 0.410 & 4 & High \\
\hline \hline Total job stress & 4.35 & 0.441 & - & High \\
\hline
\end{tabular}

It is clear from the previous table that: The level of job stress of the social workers in the private intellectual schools is high; the arithmetic mean is equal to 4.35 , and the indicators are in the order of the arithmetic mean as follows: In the first order, the dimension of stress in the work environment was with an arithmetic mean (4.46). In the second order, was the dimension of personal stress with an arithmetic mean (4.41), the third order, the dimension of emotional stress with an arithmetic mean which is equal to (4.39). Finally, in the fourth order, was the dimension of health and physical stress with an arithmetic average (4.25). Which makes the first hypothesis of the study accepted in which it was; the job stress of social workers in special education schools is expected to be high.

Second Hypothesis: It is expected that the quality of work life of social workers in special intellectual education schools will be low. 
Print ISSN: 2356-9204 Online ISSN: 2356-9212 Vol 8, Issue 1, June 2019

Table 13: The quality of work life of the social workers $(\mathrm{N}=01)$

\begin{tabular}{||l||c||c||c||c||}
\hline \multicolumn{1}{|c||}{ Dimensions } & Mean & $\begin{array}{l}\text { Standard } \\
\text { Deviation }\end{array}$ & Ranking & Level \\
\hline \hline $\begin{array}{l}\text { Participation in } \\
\text { management }\end{array}$ & 1.63 & 0.330 & 2 & low \\
\hline $\begin{array}{l}\text { Wages and financial } \\
\text { rewards }\end{array}$ & 1.51 & 0.245 & 4 & low \\
\hline \hline Social relations & 1.64 & 0.501 & 1 & low \\
\hline $\begin{array}{l}\text { Safety and functional } \\
\text { stability }\end{array}$ & 1.60 & 0.417 & 3 & low \\
\hline \hline Total Quality of career & 1.59 & 0.190 & - & low \\
\hline
\end{tabular}

It is clear from the previous table that: The level of quality of work life of the social workers in the private intellectual schools is low. The arithmetic average is 1.59 , and the indicators in the order of the arithmetic mean as follows:

In the first order, the dimension of social relations was with an arithmetic mean (1.64). In the second order, was the dimension of participation in management with an arithmetic mean of (1.63). The third order, was the dimension of safety and functional stability with an arithmetic mean (1.60). Finally, in the fourth order, was the dimension of wages and financial rewards with an arithmetic average (1.51). This makes us accept the second hypothesis of the study in which it was; "It is expected that the quality of work life of social workers in special intellectual education schools will be low."

Third Hypothesis: There is a statistically significant relationship between job stress and quality of work life among social workers in special intellectual education schools. 
Table 14: The relationship between job stress and the quality of work life of social workers

\begin{tabular}{|c|c|c|c|c|c|}
\hline Variable & $\begin{array}{l}\text { Emotion } \\
\text { al stress }\end{array}$ & $\begin{array}{c}\text { Persona } \\
\text { I stress }\end{array}$ & $\begin{array}{c}\text { Stress } \\
\text { in the } \\
\text { work } \\
\text { environ } \\
\text { ment }\end{array}$ & $\begin{array}{c}\text { Health } \\
\text { and } \\
\text { physical } \\
\text { stress }\end{array}$ & $\begin{array}{c}\text { Total } \\
\text { degree } \\
\text { of job } \\
\text { stress } \\
\text { scale } \\
\end{array}$ \\
\hline $\begin{array}{l}\text { Participation in } \\
\text { management }\end{array}$ & $-\cdot . \leqslant V 1^{* * *}$ & $-\cdot . r q 1^{* * *}$ & $-\cdot . \leqslant T^{* * *}$ & $-\cdot . \& \Delta r^{* *}$ & $-\cdot \vee \vee \theta^{* * *}$ \\
\hline $\begin{array}{l}\text { Wages and } \\
\text { financial rewards }\end{array}$ & • & $-\cdot . \leqslant I^{* *}$ & $-\cdot r \leqslant V^{* *}$ & $-\cdot \cdot r \cdot r^{* *}$ & $-\cdot V \cdot r^{* * *}$ \\
\hline Social relations & $-\cdot \cdot\left\{r r^{* *}\right.$ & $-\cdots .00 r^{* *}$ & 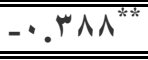 & 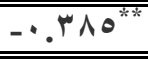 & 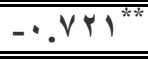 \\
\hline $\begin{array}{l}\text { Safety and } \\
\text { functional } \\
\text { stability }\end{array}$ & $-\cdot \Delta r r^{* * *}$ & $-\bullet \vee \vee \theta^{* * *}$ & $-\cdot v \cdot r^{* * *}$ & $-\cdot . \wedge \wedge \theta^{* *}$ & $-\cdot .00, * *$ \\
\hline $\begin{array}{l}\text { Total quality of } \\
\text { work life }\end{array}$ & $-\cdot . \leqslant \wedge q^{* * *}$ & $-\cdot r \wedge \theta^{* *}$ & $-\cdot V Y I^{* * *}$ & $-\cdot v \cdot r^{* * *}$ & $-\cdot .00 \leqslant * *$ \\
\hline
\end{tabular}

It is evident from the previous table that there is a statistically significant correlation at the level with (0.01) between the total of job stress scale and the dimensions of quality of work life of the social workers in special intellectual education schools, which confirms the hypothesis.

This suggests that whenever the job stress in a sample of study from social workers increases, the quality of work life decreases. Conversely, whenever the job stress decreases, their quality of work life increases. This makes us accept the third hypothesis of the study which it was "There is a statistically significant relationship between job stress and quality of work life among social workers in special intellectual education schools".

Fourth Hypothesis: There is a statistically significant relationship between the demographic variables (gender, age, marital status, academic qualification, and years of experience) and the degree of job stress in the study sample. 


\begin{tabular}{||lcc||}
\hline \multicolumn{2}{|l|}{ Egyptian Journal of Social Work (EJSW) } & http://ejsw.journals.ekb.eg \\
Print ISSN: 2356-9204 & Online ISSN: 2356-9212 & Vol 8, Issue 1, June 2019 \\
\hline \hline
\end{tabular}

Table 15: The relationship between some demographic variables and job stress among social workers

\begin{tabular}{|c|c|c|c|c|}
\hline \multirow[b]{2}{*}{$\mathbf{M}$} & \multirow[b]{2}{*}{ Demographic variables } & \multicolumn{3}{|c|}{ Job stress } \\
\hline & & $\begin{array}{c}\text { Coefficient } \\
\text { used }\end{array}$ & $\begin{array}{c}\text { Value and } \\
\text { significance }\end{array}$ & \\
\hline 1 & Gender & Ka 2 & $* 866.380$ & $(38=\mathrm{SD})$ \\
\hline 2 & Marital status & Gamma & 0.111 & \\
\hline 3 & Age & Gamma & $* * 0.180$ & \\
\hline 4 & Academic qualification & Gamma & $* * 0.190$ & \\
\hline 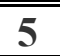 & "Years of Experience & Gamma & $* 0.165$ & \\
\hline
\end{tabular}

** Significant at 0.01

It is clear from the previous table that there is a significant relationship between one of the demographic variables (gender, age, academic qualification, years of experience) and the job stress of the social workers in the study sample. This means that the job stress varies according to some demographic variables of the social workers "sample study" and job stress is not different depending on other variables. This makes us accept the fourth hypothesis of the study that states that, there is a statistically significant relationship between the demographic variables (gender, age, marital status, academic qualification, and years of experience) and the degree of job stress in the study sample".

Fifth Hypothesis: There is a statistically significant relationship between demographic variables (gender, age, marital status, academic qualification, and years of experience) and quality of work life (sample study).

Table 16: The relationship between some demographic variables and the level of quality of work life of social workers

\begin{tabular}{|c|c|c|c|c|}
\hline \multirow[b]{2}{*}{ M } & \multirow[b]{2}{*}{ Demographic variables } & \multicolumn{3}{|c|}{ Level of quality of work life } \\
\hline & & $\begin{array}{c}\text { Coefficient } \\
\text { used }\end{array}$ & $\begin{array}{l}\text { Value and } \\
\text { significance }\end{array}$ & \\
\hline 1 & Gender & Ka 2 & 32.972 & $(23=\mathrm{SD})$ \\
\hline 2 & Marital status & Gamma & 0.131 & \\
\hline 3 & Age & Gamma & $* * 0.215$ & \\
\hline 4 & Academic qualification & Gamma & 0.114 & \\
\hline 5 & Years of Experience & Gamma & $* 0.148$ & \\
\hline
\end{tabular}


It is clear from the previous table that there is a statistically significant relationship between one of the demographic variables and the quality of work life of the social workers in the study sample, and these variables are, age and years of experience. This means that the quality of work life varies according to some demographic variables of the social workers "sample study" and quality of work life is not different depending on other variables.

This makes us accept the fifth hypothesis of the study that, there is a statistically significant relationship between demographic variables (gender, age, marital status, academic qualification, and years of experience) and quality of work life (sample study.

\section{Discussion}

Attention and development of the social work profession require paying attention to social workers who are working in various fields, especially in special intellectual education schools. Where social workers are dealing with complex cases and problems that have negative dimensions and impediment to the social worker from performing his role or reducing his effectiveness, it directly or indirectly affect the effectiveness of professional performance (Ahmed Sayed Sulaiman, 2011).

This study attempted to identify the relationship of job stress with quality of work life in a sample of social workers working in special intellectual education schools by testing some hypotheses. The results of the study indicate that the level of job stress of social workers in special intellectual education schools is high with arithmetic mean equal to 4.35. As for the quality of work life of the social workers (sample study) it is low the arithmetic mean of (1.59).

A review of the theoretical literature and previous studies found that the lack of availability of dimensions of quality of work life is one of the factors that are negatively affecting the organizational returns, including job stress in the organizations (Mansoura et al, 2013: 326). For example, the study of Marwan Hassan al-Barbari (2016), aimed at identifying the degree of availability of quality of work life dimensions and measuring the level of job combustion, found that there is a statistically significant inverse relationship between the dimensions of quality of work life and job combustion. 
The results of the study also showed that whenever the job stress in a sample of study from social workers increased, the quality of work life decreased. Conversely, whenever the job stress decreased, their quality of work life increased. These results were consistent with research hypotheses.

There are also statistically significant relationship between demographic variables (gender, age, marital status, educational qualification, years of experience) and the level of quality of work life and degree of job stress (study sample).

Through a review of several previous studies such as Ahmed Mohammed Rantissi (2015), Webb, Angela (2014), Rana Refaat Shawkat (2013), Adams, Richard. et al (2008), Marwa Abdel Raouf Mahmoud (2012), Maegli Michael (2014), Abdel Halim El Sayed (2011), Zaid Meshary Al Khubairy (2011), Jason Teven (2007), we find out that, these studies are consistent with the results of the current study on the negative impact of job stress on the quality of work life.

\section{Conclusion}

The study focused on the quality of work life and its role in reducing the phenomenon of job stress among social workers in special intellectual education schools. This study is one of the rare studies, which links the variable dimensions of the quality of work life and job stress to social workers.

The results of the study indicate that the level of job stress of social workers in special intellectual education schools is high. As for the quality of work life of the social workers (sample study), it is low. The results of the study also, showed that whenever the job stress in a sample of study from social workers increases, the quality of work life decreases. Conversely, whenever the job stress decreases, their quality of work life increase. There are also statistically significant relationship between demographic variables (gender, age, marital status, educational qualification, years of experience) and the level of quality of work life and degree of job stress (study sample). However, it is recommended to conduct many researches to confirm generalization made regarding the relationship between quality of work life and job stress. In the light of the results, the study recommends developing policies that could enhance the quality of work life of social workers in special intellectual education schools.

This study recommends the need to develop vocational intervention programs aimed at reducing the job stress of the social workers working in the special intellectual education schools through 
the exchange of experiences and focus on the pros in work. As well as guidance programs based on recreational therapy and what can be done by professional satisfaction and increased self-esteem.

Policies should also be developed to improve the situation of social workers working in special education schools by reducing work pressures, increasing incentives and providing continuous training courses.

Here also, it is necessary to focus on conducting a number of researches that deal with the relationship between the quality of work life and the job stress of the social workers.

\section{Research obstacles:}

The researchers faced many difficulties including:

1. Non-answer to the search electronically by many social workers, prompting researchers to access the sample and distribute the tool manually.

2. The reluctance of some social workers to participate in the research

3. Some schools refused to allow social workers to participate in research as a result of workloads.

\section{References:}

Abbas Jawad, Najm Al-Azzawi (2010). Strategic Functions in Human Resources Management, Dar Al-Yazuri Publishing and Distribution, Amman, Jordan.

Abdel Halim El Sayed (2011). The Relationship between Professional Intervention for Social Work and Mitigation of Job Stress among Social Workers in Preparatory Schools, Unpublished Master Thesis, Fayoum University, Cairo.

Abdelhamid, Abdellah Saber (2015): Training Needs of Social Workers Associated with the Cases of Pupils with Disabilities in Comprehensive Inclusion Schools, Journal of Social Work (Egyptian Association of Social Workers) - Egypt, p5

Abdul-Jabbar Al-Sayed Ahmed (2014): Social stress and their relationship to the quality of performance of the social workers of the Azhar institutes, unpublished master's thesis, Assiut University, Assiut.

Abu Fara, Youssef (2009). Crisis Management - Integrated Approach, Enrichment for Publishing and Distribution, Palestine. 
Adams, Richard . et al, (2008). The Compassion Fatigue: Its Use With Social Workers Following Urban Disaster, Res Soc Work Pract, 18(3).

Ahmed Mohamed Al-Rantisi (2015). The relationship between the pressures and the healthy fatigue of social workers working in the directorates of social affairs, research published in the social work journal, Faculty of Arts, Islamic University of Gaza.

Al - Rousan, Farouk (2001). The Psychology of Unusual Children, (5th Ed.) Amman: Dar Al - Fikr for Publishing and Distribution.

Anas Abbas (2011). Human Resource Management, Al-Masirah Publishing House, Amman.

Ayesha, Tedrans., (2012), "Interrelations between Quality of Work Life Dimensions and. Faculty Member Job Satisfaction in the Private Universities of. Bangladesh European", Journal of Business and Management, Vol. 4, No.2..

Brackett, M \& others (2010): Emotion regulation ability burnout, and job satisfaction among British secondary school teachers, Dissertation Abetracts international, 70 (1-8)

Daud, Nahman. (2010), "Investigating the Relationship between Quality of Work Life and Organizational Commitment amongst Employees in Malaysian Firms" International Journal of Business and Management, Vol.5, No.10.

Dhaka, et al (2011), "A Comparative Analysis of Quality of Work Life among the Employees of Local Private and Foreign Commercial Banks in Bangladesh", World Journal of Social Sciences, Vol.1, No.3..

Fapohunda, Tahre. (2013), "An Evaluation of the Perceptions and Experiences of Quality of Work Life in Nigeria", International Journal of Academic Research in Management, (IJARM) Vol. 2, No. 4 ..

Hamid, Zolfa (2014), "Identification the components of quality of work life and measuring them in faculty members of Tehran University Iranian", Journal of Management Studies (IJMS) Vol. 7, No 1..

Ibrahim Al-Mahasneh (2013). Management and Evaluation of Functional Performance between Theory and Practice, Dar Jarir Publishing and Distribution, Amman, Jordan.

Ibrahim Mohamed (2012). Strategies to deal with the psychological combustion of teachers of secondary education, Algeria. 
Iyad Al-Dajani (2010). Experience of the Islamic University of Gaza in developing the administrative performance system as an entry point for quality development, Islamic University, Gaza.

Jomaa Sayed Yousef (2006). Work Stress Management, Center for the Development of Graduate Studies and Research, Cairo University.

Maegli, Michael. (2014).Impact of an appreciative inquiry intervention on compassion fatigue among social service workers, pepperdine university.

Mahdy Zewilif (2003). Performance of Individuals, Dar Reza for Publishing and Distribution, Amman.

Mansouri, et al. (2013), "Evaluating the correlation between quality of work Life and staff burnout in Rehabilitation and Welfare centers in Ahvaz city", Jentashapir J Health Res, Vol.4, No.5،

Marwan Hassan Al-Barbari (2016). The Role of Quality of Work Life in Reducing the Functionality of Burnout of Employees of Al-Aqsa Media and Technical Production Network, Master Thesis, Graduate School of Management and Policy, Al-Azhar University.

Moayad Al-Salem (2008). Human Resource Management, Integrated Strategic Approach, Ithraa Publishing and Distribution, Amman, Jordan.

Mustafa, Youssef et al. (2014). Strategies of the worker with psychological stress among teachers of secondary education, Algeria.

Ramadan Ahmed Abdel Muttalib (2016): Estimation of training needs of social workers in special education schools, Journal of Social Work - Egyptian Association of Social Workers - Egypt, p 55

Rana Refaat Shawkat (2013): Stress on social researchers and their relationship to job satisfaction Social Science Journal, Volume 28, No. 65.

Sayed Jad El-Rab (2008). Quality of Work Life in Egyptian Business Organizations, I 7, Dar Al-Fikr Al-Arabi Publishing, Cairo.

Shaima Hussein Rabie (2015). Requirements for improving the quality of work life of social workers working in the field of Fayoum City, PhD thesis, Fayoum University, Faculty of Social Work, Department of Social Work. 
Suheir Mohammed Khairi (2007): Professional Performance of the Social Worker in the Schools of Integration of the Mentally Handicapped, Journal of Studies in Social Work and Human Sciences, Faculty of Social Work, Helwan University, p22, c2

Teven, Jasone (2007). Teacher temperament, Correlates With teacher caring burnout, and organizational outcomes Communication Education,56(3).

Webb, Angela (2014). Assessing job Satisfaction and Burnout Within the federal bureau of prisons, Psy. D . the Chicago School of professional psychology, United states Illiois.

Zaid Mishary Khalid (2011): Psychological stress and its relation to some personality traits and job satisfaction "A study of teachers of intellectual education in the State of Kuwait", $\mathrm{PhD}$ thesis, Faculty of Educational Graduate Studies, Department of Special Education, Cairo University. 
